\title{
Exploring Leishmania infantum cathepsin as a new molecular marker for phylogenetic relationships and visceral leishmaniasis diagnosis
}

Ryan Emiliano da Silva', Bruna Matarucco Sampaio ${ }^{1}$, Renata Tonhosolo², Andrea Perei ra da Costa ${ }^{3}$, Luiz Eduardo da Silva Costa ${ }^{1}$, Fernanda Ap. Nieri-Bastos ${ }^{1}$, Márcia Aparecida Sperança $a^{3,4}$ and Arlei Marcili ${ }^{1,5^{*}}$ (i)

\begin{abstract}
Background: Leishmania infantum, the etiological agent of visceral leishmaniasis, is a neglected zoonosis that requires validation and standardization of satisfactory diagnostic methodologies. Thus, the aim of the present study was to evaluate the effectiveness of cathepsin L-like protease as a target for making molecular diagnoses and as a phylogenetic marker enabling to understand the intraspecies variations and evolutionary history of $L$. infantum in Brazil.

Methods: We used 44 isolates of L. infantum. The cathepsin L-like gene fragments were amplified, sequenced, manually aligned and analyzed using inference methods. The sequences generated were used to search and design oligonucleotide primers to be used in reactions specific to the target parasite.

Results: The cathepsin L-like gene did not show any intraspecies variability among the isolates analyzed. The pair of primers proposed amplified the target deoxyribonucleic acid (DNA) of $L$. infantum isolates and were effective for DNA amplification at concentrations of as low as $10^{-11} \mathrm{ng} / \mu \mathrm{l}$. The proposed marker did not present cross-reactions with other hemoparasites. When used for making the diagnosis in a panel of clinical samples from dogs, a positivity rate of 49.03\% (102/208) was obtained, versus $14.42 \%$ (30/208) for a ribosomal internal transcribed spacer (ITS) marker. In samples from sandflies, the rate was $6.25 \%$ and from humans, $14.28 \%$.
\end{abstract}

Conclusions: The results described in this work allow us to infer that CatLeish-PCR is a sensitive and specific marker for use in diagnostic trials of $L$. infantum and in clinical and epidemiological surveys.

Keywords: Leishmania (Leishmania) infantum, Cysteine proteases, Cathepsin L-like, Molecular diagnosis

\section{Background}

Leishmania (Leishmania) infantum is a flagellate protozoon with a heterogenic cycle that belongs to the genus Leishmania, which is in the family Trypanosomatidae of the order Kinetoplastida [1]. This parasite is the etiological agent for visceral leishmaniasis, a zoonosis with worldwide distribution. Most of the cases are

\footnotetext{
* Correspondence: amarcili@usp.br

${ }^{1}$ Departamento de Medicina Veterinária Preventiva e Saúde Animal,

Faculdade de Medicina Veterinária e Zootecnia, Universidade de São Paulo,

Av. Prof. Dr. Orlando Marques de Paiva, 87, São Paulo, SP 05508-270, Brazil

${ }^{5}$ Medicina Veterinária e Bem estar animal, Universidade Santo Amaro, São

Paulo, SP, Brazil

Full list of author information is available at the end of the article
}

concentrated in Bangladesh, Nepal, India, South Sudan and Brazil. The development of this parasite comprises two morphological forms, whose main differences are the position of the kinetoplast in relation to the nucleus and the presence of a free flagellum associated with the undulating membrane $[2,3]$. The promastigote form is found in arthropod vectors, represented by insects of the phlebotomine group [4], while amastigote forms are found inside cells of the mononuclear phagocytic system of vertebrate hosts such as rodents, marsupials, bats, canids and humans $[5,6]$.

The severity of the disease is explained by the high virulence of its etiological agents, which results from the 
action of a set of functional molecules with intense biological activity in their hosts. The role of protease inhibitors in the development of pathogenic mechanisms was investigated [7]. These enzymes can be divided into endopeptidases and exopeptidases, depending on the site of hydrolysis. If the residue present at the catalytic site is taken into account, they are divided into metalloproteases, serine proteases, aspartic proteases and cysteine proteases [8]. In the genus Leishmania, cysteine proteases are the most abundant class of enzymes and are concentrated inside megasomes, where they act towards regulation of metabolic routes, cell differentiation in vertebrates and vectors, cell invasion and transposition of tissue barriers, degradation of hemoglobin and other hematopoietic proteins, evasion of the immune response, activation of inflammatory responses and programmed cell death [9].

Cathepsin L-like cysteine proteases in Leishmania have three isoforms, named cysteine protease A (CPA), cysteine protease $\mathrm{B}(\mathrm{CPB})$ and cysteine protease $\mathrm{C}(\mathrm{CPC})$. These are biochemically organized into four domains (predomain, prodomain, catalytic domain, C-terminal extension) that result from expression of a multigenic family arranged in tandem. In the specific case of $L$. infantum, two isoforms are expressed, the CPB isoform expressed in the promastigote forms found in the insect vectors and the CPA isoform, in which transcriptomic studies revealed a unique expression profile of the amastigote forms [10].

They are, therefore, used to construct phylogenetic inferences of close sequences and to resolve problems regarding polytomy and inferences of low support $[11,12]$. Cathepsin genes have already been used for understanding phylogenetic relationships and as a target for making molecular diagnoses regarding other trypanosomatid species [13-15]. However, there are no studies that characterize this gene in L. infantum or that investigate it as a possible diagnostic marker that might help to solve recurrent problems regarding diagnostic investigation of this parasite within the clinical routine and in epidemiological investigations.

Despite the high importance of this disease, there is some difficulty in standardizing diagnostic methodologies with high predictive values for reservoir surveys. Making a direct diagnosis is invasive and laborious, and only low levels of sensitivity are reached [16-18]. The serological tests also have a series of technical limitations, such as low specificity values resulting from crossreactions with other trypanosomatids, low concordance indices between different serological tests and lack of consensus regarding the nature and use of the antigenic product to be employed [19-22].

Thus, the objective of this study was to evaluate the CPA isoform of cathepsin L-like sequences as a marker for genetic analysis on intraspecific variability of $L$. infantum and as a marker for making molecular diagnoses on visceral leishmaniasis.

\section{Methods \\ Leishmania isolates, DNA preparation, amplification and sequencing of cathepsin L-like gene}

DNA from 44 Leishmania isolates (Table 1) was extracted from culture supernatants using the phenol-chloroform method and from primary samples (human blood, urine, conjunctival swabs from dogs and sandfly material) in accordance with the protocol established for the Purelink kit (Thermo Fisher Scientific Inc., 2012, USA).

First of all, the extracted DNA samples were quantified and submitted to conventional polymerase chain reactions (PCR) using the specific primers to Mammalian Cytochrome B as a constitutive gene, to ensure the quality of the samples [23]. After this quality control, the DNA samples were submitted to the PCR reactions using high-fidelity Taq DNA polymerase with the specific primers designated for Cathepsin L-like CPA from Leishmania [24] which comprised a fragment of around 893 base pairs (bp).

All the isolates were included in the Brazilian Trypanosomatid Collection (Coleção Brasileira de Tripanossomatídeos, CBT) of the School of Veterinary Medicine of the University of São Paulo, Brazil.

\section{Phylogenetic analysis}

The sequences obtained were aligned with sequences retrieved from GenBank using ClustalX [25] and were adjusted manually using GeneDoc [26] and then deposited in GenBank (Table 1). The cathepsin L-like CPA sequences were used to construct a phylogenetic tree using maximum parsimony, as implemented in PAUP version $4.0 \mathrm{~b} 10$ [27] with 500 bootstrap replicates. Bayesian analysis was performed using MrBayes v3.1.2 [28] with 1, 000,000 replicates. The first $25 \%$ of the trees represented burn-in, and the remaining trees were used to calculate Bayesian posterior probability.

\section{Standardization of $L$. infantum-specific assay based on cathepsin L-like protease}

The aligned cathepsin L-like CPA gene sequences were used to search for consensus regions and to design specific primers for diagnosing L. infantum. The criteria used to define the primer pair were the guanine-tocytosine ratio, formation of guanidine/cytosine (GC) staples, formation of self-homologies, self-dimer formation measured using the $\Delta G$ value, melting temperature and in silico specificity of the primers through BLASTn.

A specific PCR procedure (designated CatLeishPCR) was developed for amplification of $223 \mathrm{bp}$ of genomic DNA from L. infantum, using the CatLeishF primer (5' GACAACGGCACCGTCGGCGCCAAAAT 
Table 1 Leishmania infantum isolates, host, geographical origin and sequences of Cathepsin L-like employed in the phylogenetic analysis performed in this study

\begin{tabular}{|c|c|c|c|c|}
\hline$\overline{\mathrm{CBT}^{\mathrm{a}}}$ & Host & Geographical orig & & Accession number $^{b}$ \\
\hline 01 & Canis familiaris & & $\mathrm{SP}$ & MH427793 \\
\hline 12 & Canis familiaris & Recreio & RJ & MH427794 \\
\hline 13 & Canis familiaris & Mangaratiba & RJ & MH427795 \\
\hline 14 & Canis familiaris & Ilha Grande & RJ & MH427796 \\
\hline 15 & Canis familiaris & Barra da Tijuca & RJ & MH427797 \\
\hline 16 & Canis familiaris & Recreio & RJ & MH427798 \\
\hline 17 & Canis familiaris & Cuiabá & MT & MH427799 \\
\hline 18 & Canis familiaris & Ilha de Guaratiba & RJ & MH427800 \\
\hline 20 & Canis familiaris & Cuiabá & MT & MH427801 \\
\hline 22 & Canis familiaris & Caucaia & CE & MH427802 \\
\hline 23 & Canis familiaris & Fortaleza & CE & MH427803 \\
\hline 24 & Canis familiaris & Jequié & $\mathrm{BA}$ & MH427804 \\
\hline 25 & Canis familiaris & Campo Grande & MS & MH427805 \\
\hline 26 & Canis familiaris & & DF & MH427806 \\
\hline 27 & Cerdocyon thous & & PA & MH427807 \\
\hline 28 & Canis familiaris & Teresina & $\mathrm{Pl}$ & MH427808 \\
\hline 29 & Canis familiaris & Teresina & $\mathrm{Pl}$ & MH427809 \\
\hline 30 & Canis familiaris & Uruguaiana & RS & $\mathrm{MH} 427810$ \\
\hline 31 & Canis familiaris & Uruguaiana & RS & MH427811 \\
\hline 34 & Canis familiaris & Petrolina & $P E$ & MH427812 \\
\hline 37 & Canis familiaris & Petrolina & $P E$ & MH427813 \\
\hline 39 & Canis familiaris & Santarém & PA & MH427814 \\
\hline 40 & Canis familiaris & Santarém & PA & MH427815 \\
\hline 43 & Canis familiaris & Santarém & PA & MH427816 \\
\hline 44 & Canis familiaris & Santarém & PA & MH427817 \\
\hline 49 & Canis familiaris & Campo Grande & MS & MH427818 \\
\hline 50 & Canis familiaris & Campo Grande & MS & MH427819 \\
\hline 54 & Canis familiaris & Teresina & $\mathrm{Pl}$ & MH427820 \\
\hline 55 & Canis familiaris & Teresina & $\mathrm{Pl}$ & MH427821 \\
\hline 56 & Canis familiaris & Campo Grande & MS & MH427822 \\
\hline 57 & Canis familiaris & Campo Grande & MS & MH427823 \\
\hline 62 & Canis familiaris & Petrolina & $\mathrm{PE}$ & MH427824 \\
\hline 96 & Canis familiaris & Caxias & MA & MH427825 \\
\hline 105 & Canis familiaris & Natal & $\mathrm{RN}$ & MH427826 \\
\hline 106 & Canis familiaris & Natal & RN & MH427827 \\
\hline 107 & Canis familiaris & Natal & RN & MH427828 \\
\hline 108 & Canis familiaris & Natal & $\mathrm{RN}$ & MH427829 \\
\hline 124 & Canis familiaris & Natal & RN & MH427830 \\
\hline 125 & Canis familiaris & Natal & $\mathrm{RN}$ & MH427831 \\
\hline 126 & Canis familiaris & Natal & $\mathrm{RN}$ & MH427832 \\
\hline 153 & Canis familiaris & São Domingos & MA & MH427833 \\
\hline 179 & Canis familiaris & Patos & PB & MH427834 \\
\hline
\end{tabular}

Table 1 Leishmania infantum isolates, host, geographical origin and sequences of Cathepsin L-like employed in the phylogenetic analysis performed in this study (Continued)

\begin{tabular}{lllll}
\hline CBT $^{\mathrm{a}}$ & Host & Geographical origin & Accession number \\
\hline 211 & Homo sapiens & Marília & SP & MH427835 \\
212 & Homo sapiens & Marília & SP & MH427836 \\
\hline
\end{tabular}

Brazilian states: BA, Bahia; CE, Ceará; DF, Distrito Federal; MA, Maranhão; MS, Mato Grosso do Sul; MT, Mato Grosso; PA, Pará; PB, Paraíba; PE, Pernambuco; PI, Piauí; RJ, Rio de Janeiro; RN, Rio Grande do Norte; RS, Rio Grande do Sul; SP, São Paulo

${ }^{a}$ Coleção Brasileira de Tripanossomatídeos

${ }^{\mathrm{b}}$ GenBank acession number

AAAAG 3') and CatLeishR primer (5' CAGTAC GGCGGTTTCGCTTGTCTGTTGAAGC 3') (Fig. 1). The standard conditions for amplification of the cathepsin L-like CPA sequences comprised 34 cycles of denaturation at $94{ }^{\circ} \mathrm{C}$ for $1 \mathrm{~min}$, annealing at $64^{\circ} \mathrm{C}$ for $1 \mathrm{~min}$ and extension at $72^{\circ} \mathrm{C}$ for $45 \mathrm{~s}$.

\section{Sensitivity and specificity assay on CatLeish-PCR}

For sensitivity tests, DNA from $L$. infantum was serially diluted at the concentrations of $1 \times 10^{-7}, 1 \times 10^{-8}, 1 \times$ $10^{-9}, 1 \times 10^{-10}, 1 \times 10^{-11}, 1 \times 10^{-12}, 1 \times 10^{-13}, 1 \times 10^{-14}$ and $1 \times 10^{-15} \mathrm{ng} / \mu \mathrm{l}$.

Specificity tests were performed on DNA samples from other parasite species in the genus Leishmania, including: Leishmania (Viannia) braziliensis, Leishmania (Viannia) guyanensis, Leishmania (Viannia) naiffi, Leishmania (Leishmania) amazonensis, Leishmania (Leishmania) mexicana, Leishmania (Sauroleishmania) gymnodactyli, Leishmania (Sauroleishmania) adleri, Leishmania (Sauroleishmania) tarentolae and Leishmania (Mundinia) enriettii. In addition, the following species in the genus Trypanosoma were tested: Trypanosoma dionisii, Trypanosoma terrestris, Trypanosoma cruzi, Trypanosoma cruzi marinkellei, Trypanosoma theileri and Trypanosoma gennarii; along with two other pathogenic species that are common in dogs: Babesia canis and Ehrlichia canis.

\section{Application of CatLeish-PCR to clinical samples}

CatLeish-PCR was tested on a panel of clinical samples of purified DNA obtained from dogs in endemic and nonendemic regions in São Paulo state, Brazil. In addition, blood samples (prepared on filter paper), conjunctival swabs and urine samples from dogs that were known to be positive in the parasitological test were used. DNA samples obtained from human patients blood from Marília, São Paulo state and DNA extracted from sandflies caught in Bom Jesus dos Perdões, São Paulo state were also tested in pools. All samples were further tested using the ITS rDNA marker [29]. 


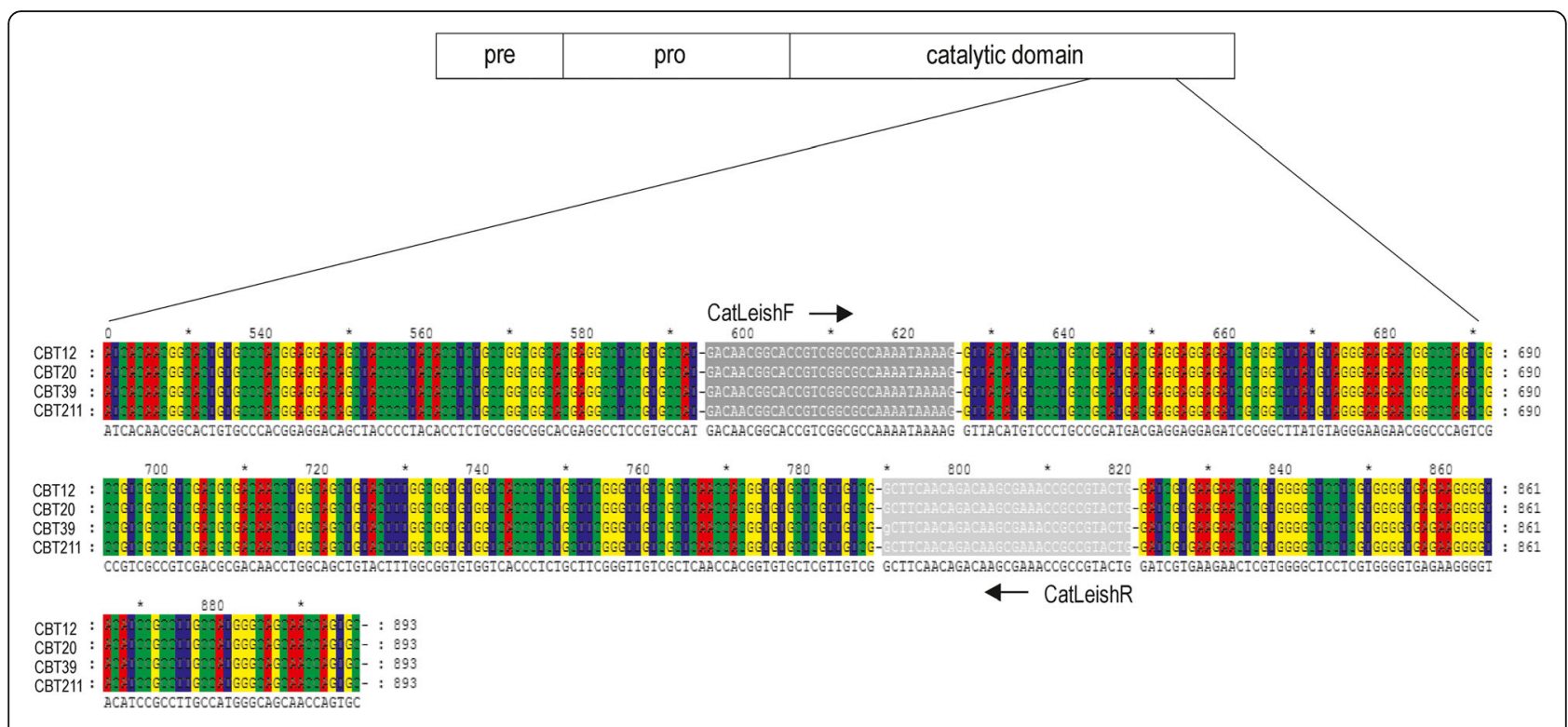

Fig. 1 Alignment of cathepsin L-like CPA sequences from Leishmania infantum. Schematic representation of primers used for PCR amplification

\section{Results}

Forty-four sequences were obtained from cathepsin L-like CPA and they were all identical, without polymorphism, and presented $99 \%$ similarity with cysteine peptidase isoform A of Leishmania infantum (XM_001465076.1) from Europe. The sequences of cathepsin L-like CPA from $L$. infantum were identical and all isolates were clustered together (100\% bootstrap/100\% posterior probability and 100\% similarity) (Fig. 2).

Leishmania species were aggregated in a monophyletic group (Fig. 2). The different species of the genus Leishmania were segregated into four groups: I. Leishmania species with mucocutaneous clinical manifestations, including L. guyanensis, $L$. braziliensis and $L$. panamensis (0.1\% divergence of sequences and $100 \%$ bootstrap and 1.0 posterior probability); II. Species with cutaneous manifestations, including $L$. pifanoi, $L$. mexicana and $L$. amazonensis $(0.52 \%$ divergence of sequences and $100 \%$ bootstrap and 1.0 posterior probability); III. Leishmania species causing cutaneous "oriental sore", including L. major and L. aethiopica (1.53\% divergence of sequences and 100\% bootstrap and 1.0 posterior probability); and IV. New and Old-World species of visceral leishmaniasis $(0.14 \%$ divergence of sequences and 100\% bootstrap and 1.0 posterior probability), separated according to the geographical origin of the isolates (Fig. 2).

The in silico analyses on the primers proposed for the specific PCR did not indicate any possibility of formation of GC staples, self-dimers and auto-homologies. The CatLeishF primer showed a GC ratio of $54.5 \%$ with an estimated melting temperature of $66.2^{\circ} \mathrm{C}$, whereas the CatLeishR primer had a GC ratio of $57.6 \%$ with a melting temperature corresponding to $65.5^{\circ} \mathrm{C}$. In BLASTn analysis, these primers were specific for $L$. infantum, with no homology containing sequences from other species deposited in the database.

CatLeish-PCR reactions with genomic DNA from $L$. infantum isolates demonstrated that there was a correct amplification, since amplicon sequencing revealed in BLASTn a percentage of $99 \%$ similarity to deposited sequences of cysteine protease genes from European strains of $L$. infantum (XM_001465076.1) and identical to American L. infantum sequences obtained in this study. Sensitivity measurement demonstrated that the markers were efficient at amplifying the target DNA and forming detectable bands at concentrations of up to $10^{-11} \mathrm{ng} / \mu \mathrm{l}$ (Fig. 3).

Different species of the genus Leishmania were tested and there was no cross-amplification with any of the species epidemiologically associated with the cutaneous or tegumentary leishmaniasis complex in Brazil. When the molecular diagnosis was tested against hemoparasites belonging to the genera Babesia, Ehrlichia and Trypanosoma, there was no amplification (Fig. 3).

The use of CatLeish-PCR in the panel of clinical samples revealed that frequency of positive dogs was $49.03 \%$, thus contrasting with the $14.42 \%$ achieved through using primers for the ribosomal ITS gene. All samples that were positive in the reactions for the ITS gene were positive in reactions for the cathepsin gene. In the human samples, $6.25 \%$ were positive, whereas in samples from sandflies, the positivity was $14.28 \%$ in pools (Table 2).

The samples from parasitologically positive dogs showed different rates of positivity according to the material tested. Urine samples showed 33\% positivity, conjunctival swabs $50 \%$, samples preserved on filter paper $100 \%$ and whole blood samples $100 \%$. 


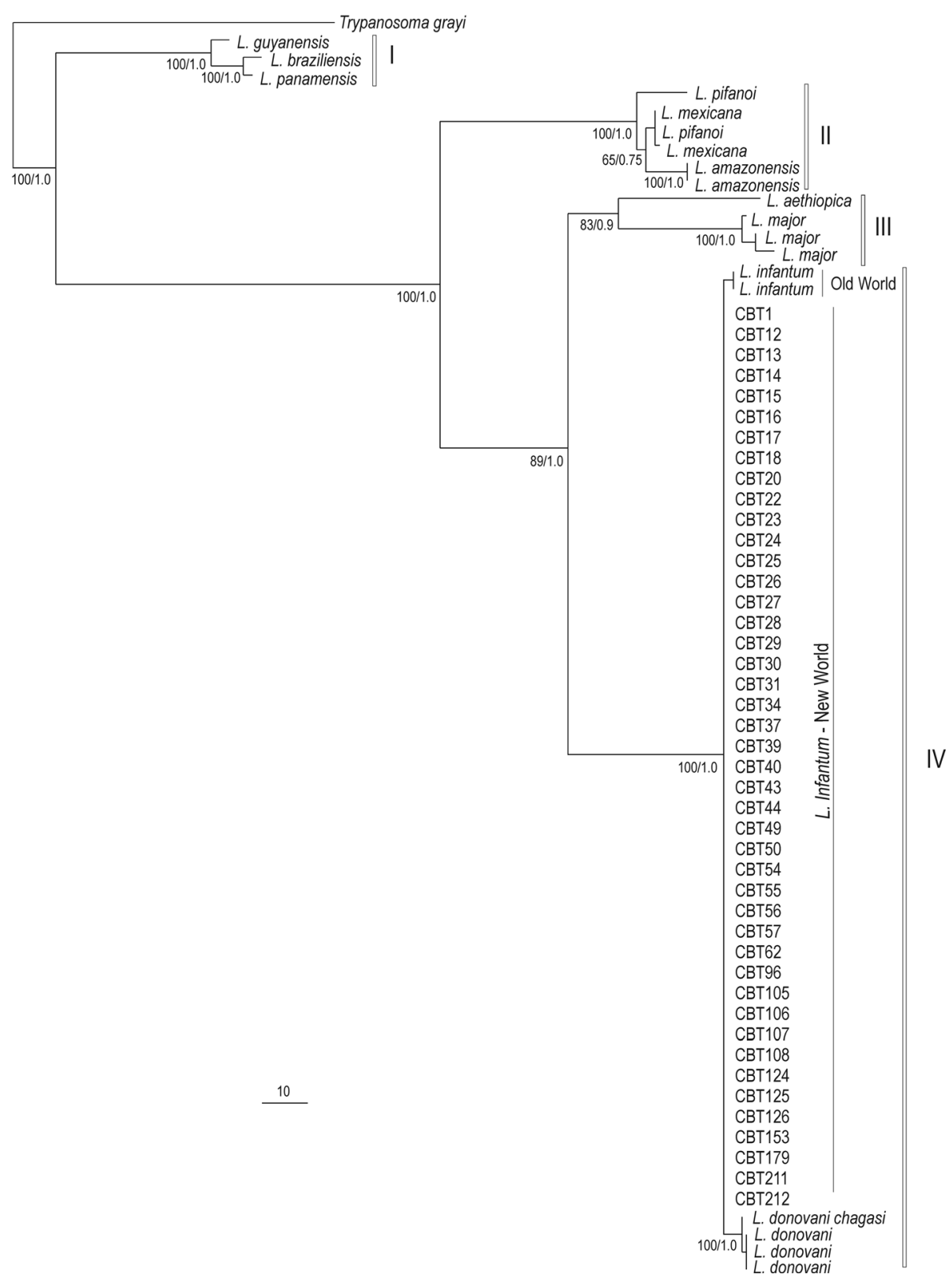

Fig. 2 Dendrogram based on 44 cathepsin L-like sequences from Leishmania infantum, which was used for making maximum parsimony and Bayesian inferences with 892 characteristics. Numbers at nodes are the support values for the major branches (bootstrap/posterior probability; 500 replicates). The sequences obtained in the present study are underlined

The CatLeish-PCR was replicated several times during standardization with DNA samples from American $L$. infantum isolates, and subsequently technical replication was tested with clinical samples. Regardless of the samples tested, the technical replication and amplification standard were maintained (Additional file 1).

\section{Discussion}

The phylogenetic inferences from maximum parsimony and Bayesian analyses revealed a pattern of high similarity for L. infantum isolates, as observed in inferences based on SSUrDNA and gGAPDH genes [30]. The segregation of $L$. infantum from Europe and America corroborates the notion that this species was introduced to the Americas during the colonization period [30].

This absence of divergence, even among isolates from biomes with different climates, rainfall, vegetation cover and availability of hosts and arthropod vectors, corroborates the theory that this parasite is not autochthonous to the Americas [31]. This finding indicates that the event leading to introduction of this parasite to the New 


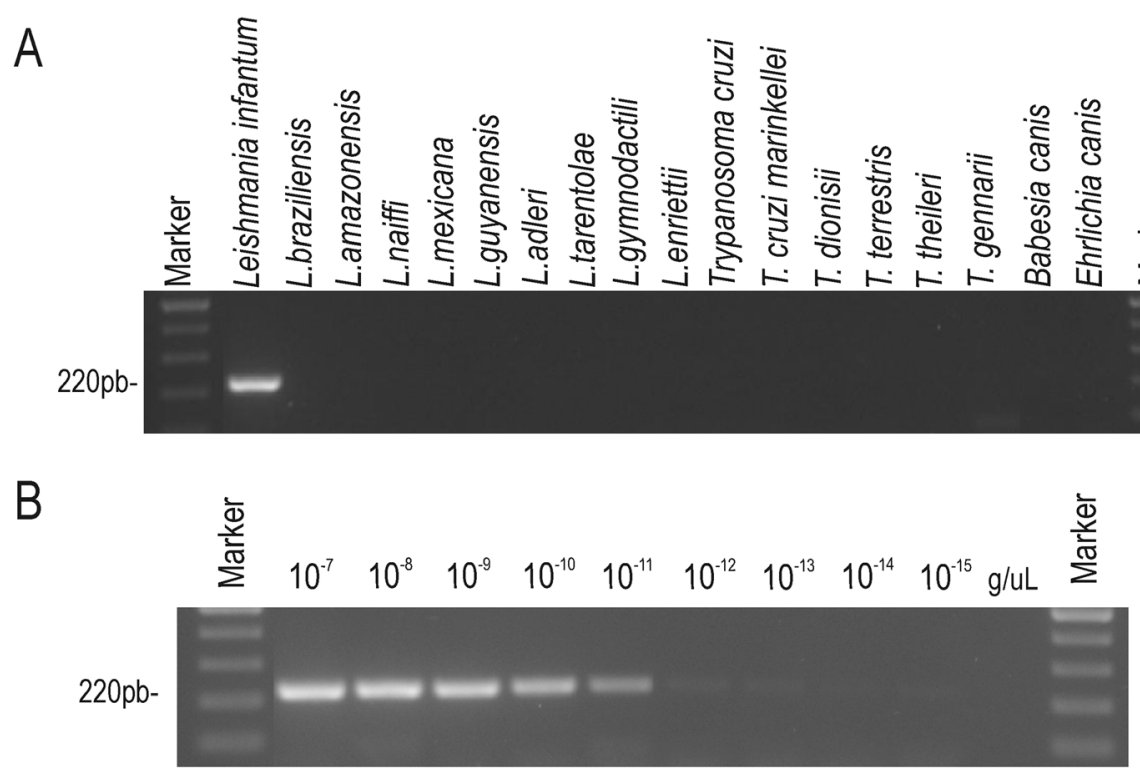

Fig. 3 CatLeish-PCR for diagnosis of Leishmania infantum based on Cathepsin L-like sequences. a Specificity analysis using DNA, Leishmania and Trypanosoma sequences and other hemoparasites from dogs (Babesia and Ehrlichia). b Sensitivity analysis using DNA from Leishmania infantum in different concentrations

World was recent. It can therefore probably be dated to the process of Ibero-American colonization that began in the fifteenth century, caused by the arrival of infected dogs and rodents [32]. Focusing only on a few specific genes we can speculate that this short evolutionary time interval would be insufficient for the appearance and fixation of possible mutations in the population.

These results refute the hypothesis of a scenario in which the parasite responsible for cases of visceral leishmaniasis is native to the Americas [30-33]. Thus, the argument that the parasite is autochthonous in that it is adapted to parasitism in other wild fauna reservoirs can be countered through attributing this adaptation to the eclectic dietary habits of the vector insects [34].

The phylogenetic analysis on the cathepsin L-Like CPA gene showed clustering that reflects the distinct

Table 2 Positivity of naturally infected biological samples based on Cathepsin L-like of Leishmania infantum (CatLeish-PCR) marker

\begin{tabular}{lll}
\hline Samples (number) & \multicolumn{2}{l}{ Positives samples (\%) } \\
\cline { 2 - 3 } & CatLeish-PCR & ITS \\
\hline Dogs blood (208) & $49,03(102)$ & $14,42(30)$ \\
Dogs urine (3) & $33(1)$ & \\
Dogs conjuntival swab (4) & $50(2)$ \\
Dogs blood in filter paper (4) & $100(4)$ \\
Human blood (50) & $6,25(3)$ \\
Sand flies (21) & $14,28(3)$ \\
\hline
\end{tabular}

clinical manifestations of Leishmania infection, and it was similar to amino acid analyses on cysteine proteases [24]. In addition, the topology generated using the cathepsin L-like gene also corroborates data generated using ribosomal spacers and cytochrome B [35, 36].

The inferences correctly solved the differentiation of the species that are considered to be the etiological agent of tegumentary forms of the disease. One of the clades grouped L. guyanensis, L. panamensis and L. braziliensis, and this reflected the findings of studies in which, analyzing otorhinolaryngological conditions, most of the etiology of mucocutaneous leishmaniasis was attributed to L. braziliensis and L. panamensis, as well as results in which clinical situations of mucosal involvement were attributed to $L$. guyanensis [37, 38].

A second group included L. amazonensis and L. mexicana, species that have been widely associated with cutaneous manifestations of tegumentary leishmaniasis in the New World [39-43]. The L. pifanoi sequences were positioned in this same group. Although this species has lower epidemiological impact regarding disease transmission, it belongs to the L. mexicana complex [44]. Therefore, this result corroborates the data demonstrating similarity among the species of this complex, with regard to proposing specific markers for kinetoplast DNA (kDNA) [45].

These results confirm that the cathepsin L-like CPA gene is a good marker for phylogenetic positioning of species of the genus Leishmania, which suggests that this gene may be a good target for making the molecular diagnosis of 
leishmaniasis. This would enable satisfactory differentiation between the clinical forms of the disease, including among the variants of the tegumentary forms, which may aid in prescribing therapy, establishing the medical prognosis for the disease and mitigating the recurrent problems of specific diagnosis. We agree that the number of isolates collected in this work is sufficient to portray the dispersal of the parasite in Brazil.

Cathepsin gene-based assays have shown excellent results with regard to diagnosing the following Trypanosoma species: T. vivax [13], T. congolense [46], T. theileri [47], T. cruzi [48] and T. rangeli [49]. However, the low numbers of copies of this gene in the genome are very specific and especially sensitive [13].

Cathepsin L-like protease is differentially expressed in different forms of the parasite [50,51]. The CPA isoform is preferentially expressed in amastigote forms. In vertebrates (both human and animal hosts), amastigotes are the replicative form and cathepsin L-like CPA is continuously expressed [24]. The expression pattern of cathepsin L-like CPA and the presence of immunogenic epitopes may indicate it as an interesting target in diagnostic-serological tests, which are preferentially used in the clinical routine [25].

The diagnostic marker based on the cathepsin L-like CPA gene has shown high sensitivity and was specific for $L$. infantum, which enables direct use in clinical samples both in non-endemic areas with imported cases and in endemic areas in which different species of Leishmania may be circulating. Thus, it has been proven to be effective for epidemiological surveys on human hosts, animal reservoirs and arthropod vectors. Another advantage that makes CatLeish-PCR feasible is that there is no need for complementary restriction enzyme digestion steps or use of robust high-resolution melting equipment for identifying $L$. infantum, which makes the method less costly and less cumbersome than other methodologies that are available [52].

In comparison with the markers for the ITS gene, CatLeish-PCR demonstrated higher prevalence of leishmaniasis, which thus corroborated the diagnostic sensitivity of the marker. The marker was effective in making the diagnosis, both from positive swab samples from conjunctival lesions and from blood samples fixed on filter paper, reinforcing the high sensitivity of CatLeishPCR. The positive animals in the parasitological examination were also positive when submitted to molecular diagnosis based on the cathepsin L-like gene, except for the urine samples given the low amount of DNA in two animals. This versatility is important because samples fixed on filter paper are easier to transport and store, given their stability, as well as exempt invasive collection methodologies [29].

The diagnostic method works very well for blood samples and even though the number of samples from other sources is reduced, the method borrows our hypothesis of good molecular marker for diagnosis in biological samples with DNA. Amplification was observed even in samples extracted from urine, whose DNA concentration is considerably reduced, corresponding only to fragments of the dead parasite excreted in the urinary system [53]. It should be noted that even with low levels of positivity in the assays using biological samples as a template, we still support our indication of the use of the Cathepsin gene for PCR diagnosis, since even in biological samples where the genetic material of the parasites is scarce or damaged, we obtained satisfactory amplifications. Considering this, CatLeish-PCR may have potential for monitoring the remission of infection in patients with visceral leishmaniasis and as an indicator of the efficacy of possible therapeutic approaches [54].

The results presented here allow us to propose that CatLeish-PCR is a tool that can be used for diagnosing visceral leishmaniasis. It surmounts the recurrent problems of low sensitivity that direct visualization methodologies present and those of low specificity and agreement among the serological methods that have preferentially ben recommended for diagnosing this disease [55]. The molecular diagnostic assays used and described in the literature have low sensitivity and specificity. Markers based on the cytochrome b gene are non-specific [56]. Markers based on genes present in the kinetoplast have high sensitivity, but their specificity is low $[57,58]$. Markers based on ribosomal genes are specific, but not very sensitive [59]. Other assays such as restriction fragment length polymorphism (PCR-RFLP) have been standardized, but these raise the cost of making the diagnosis or still require sequencing of the product [60-62].

Epidemiological studies are important for recognizing active transmission cycles or introduction of parasites into new areas. Therefore, precise diagnostic methods are essential for diagnosing the presence of a parasite that is still emerging in many regions. Moreover, making a precise diagnosis minimizes the need to destroy dogs, which are the main reservoirs, given that in some countries this prophylactic measure used in combating human leishmaniasis.

\section{Conclusion}

This is the first work that characterizes the CPA isoform of the L-like cathepsin gene of L. infantum, demonstrating the lack of genetic variability among the Brazilian isolates of $L$. infantum. We propose that the gene studied here be an efficient phylogenetic marker for parasites of the genus Leishmania, and also the developed CatLeish-PCR has been shown to be sensitive and specific for the effective clinical diagnosis of this zoonosis in dogs and humans. 


\section{Supplementary information}

Supplementary information accompanies this paper at https://doi.org/10. 1186/s12879-019-4463-8.

Additional file 1. Amplification patterns of CatLeish-PCR for diagnosis of Leishmania infantum in samples from dogs, humans and sand flies.

\section{Abbreviations}

C: Cytosine; CBT: Coleção Brasileira de Tripanossomatídeos; CPA: Cysteine protease A; CPB: Cysteine protease B; CPC: Cysteine protease $C_{\text {; }}$ DNA: Deoxyribonucleic acid; G: Guanidine; ITS: Internal transcribed spacer kDNA: kinetoplast deoxyribonucleic acid; PCR: Polymerase chain reaction; PCR-RFLP: Restriction fragment length polymorphism

\section{Acknowledgments}

We would like to thank to veterinary Vilma Pereira da Costa and all the people who assisted this study in the different locations studied.

\section{Authors' contributions}

RES and AM conceived the study and designed the experiments; RES, BMS, LESC, APC, FNB and MAS, assisted with sample collection, performed the experiments and analyzed the data; RES, RT and AM prepared the paper. All authors read and approved the final version of the manuscript.

\section{Funding}

This research was financially supported by Fundação de Amparo a Pesquisa do Estado de São Paulo (FAPESP) process number 2010/50886-7, and Conselho Nacional de Desenvolvimento Científico e Tecnológico (CNPq) process number 404249/2016-7 and Coordenação de Aperfeiçoamento de Pessoal de Nível Superior (CAPES). RES scholarship from CNPq, BMC from CAPES and APC from FAPESP,

\section{Availability of data and materials}

The accession numbers of GenBank from sequences obtained in this study are described in Table 1

\section{Ethics approval and consent to participate}

The human samples were transferred by the Laboratory of Pathogens from Center of Natural and Human Sciences from Universidade Federal do ABC and approved by Ethics Committee for Human research from Federal University of ABC (number 883722718900005594). The clinical samples from dogs and sandflies procedures were endorsed by the Ethics Committee for Animal Use of the University of São Paulo, Brazil (number 7584250216) according National Council for Control of Animal Experimentation.

\section{Consent for publication}

Not applicable.

\section{Competing interests}

The authors declare that they have no competing interests.

\section{Author details}

'Departamento de Medicina Veterinária Preventiva e Saúde Animal, Faculdade de Medicina Veterinária e Zootecnia, Universidade de São Paulo, Av. Prof. Dr. Orlando Marques de Paiva, 87, São Paulo, SP 05508-270, Brazil. ${ }^{2}$ Faculdade de Medicina, Universidade Santo Amaro, São Paulo, SP, Brazil. ${ }^{3}$ Ciência Animal, Universidade Estadual do Maranhão, São Luís, MA, Brazil. ${ }^{4}$ Centro de Ciências Naturais e Humanas, Universidade Federal do ABC, São Bernardo do Campo, SP, Brazil. ${ }^{5}$ Medicina Veterinária e Bem estar animal, Universidade Santo Amaro, São Paulo, SP, Brazil.

Received: 21 February 2019 Accepted: 11 September 2019

Published online: 28 October 2019

\section{References}

1. Honigberg BM. A contribution to systematics of the non-pigmented flagellates. In: Ludvik J, Lom J, Vavra J, editors. Progress in Protozoology. New York: Academic Press; 1963. p. 68-9.
2. Wallace FG. Biology of the Kinetoplastida of Arthropods. In: Lumsden WHR, Evans DA, editors. Biology of the Kinetoplastida. New York: Academic Press; 1979. p. 213-40

3. Vickerman K. The evolutionary expansion of the trypanosomatid flagellates. Int J Parasitol. 1994;24:1317-31.

4. Galvis-Ovallos F, Silva MD, Bispo GB, Oliveira AG, Neto JR, Malafronte RD, et al. Canine visceral leishmaniasis in the metropolitan area of São Paulo: Pintomyia fischeri as potential vector of Leishmania infantum. Parasite. 2017;24:2.

5. Deane LM, Deane MP. Encontro de Leishmanias nas vísceras e na pele de uma raposa, em zona endêmica de calazar, nos arredores de Sobral, Ceará. Hospital. 1954;45:419-21.

6. Costa AP, Costa FB, Soares HS, Ramirez DG, Mesquita ET, Gennari SM, et al. Trypanosoma cruzi and Leishmania infantum chagasi infection in wild mammals from Maranhão state, Brazil. Vector Borne Zoonotic Dis. 2015:15:656-66.

7. Gomes CB, Silva FS, Charret KS, Pereira BAS, Finkelstein LC, Souza RS, et al. Increasing in cysteine proteinase B expression and enzymatic activity during in vitro differentiation of Leishmania (Viannia) braziliensis: first evidence of modulation during morphological transition. Biochimie. 2016;133:28-36.

8. Silva-López RE. Proteases de Leishmania: novos alvos para o desenvolvimento racional de fármacos. Quím Nova. 2010;33:1541-8.

9. Agallou M, Margaroni M, Athanasiou E, Toubanaki D, Kontonikola K, Karidi K, et al. Identification of BALB/c immune markers correlated with a partial protection to Leishmania infantum after vaccination with a rationally designed multi-epitope cysteine protease a peptide-based nanovaccine. PLoS Negl Trop Dis. 2017;11:1.

10. Mundodi V, Kucknoor AS, Gedamu L. Role of Leishmania (Leishmania) chagasi amastigote cysteine protease in intracelular parasite survival: studies by gene disrruption and antisense mRNA inhibition. BMC Mol Biol. 2005;6:3.

11. Mottram JC, Coombs GH, Alexander J. Cysteine peptidases as virulence factors of Leishmania. Curr Opin Microbiol. 2004;7:375-81.

12. Casgrain PA, Martel C, McMaster WR, Mottram JC, Olivier M, Descoteaux A. Cysteine peptidase $B$ regulates Leishmania mexicana virulence through the modulation of GP63 expression. PLoS Pathog. 2016:12:5.

13. Cortez AP, Rodrigues AC, Garcia HA, Neves L, Batista JS, Bengaly Z, et al. Cathepsin L-like genes of Trypanosoma vivax from Africa and South America characterization, relationships and diagnostic implications. Mol Cell Probes. 2008:23:44-51.

14. Garcia HA, Kamyingkird K, Rodrigues AC, Jittapalapong S, Teixeira MM, Desquesnes M. High genetic diversity in field isolates of Trypanosoma theileri assessed by analysis of cathepsin L-like sequences disclosed multiple and new genotypes infecting cattle in Thailand. Vet Parasitol. 2011;180:363-7.

15. Yokoyama N, Sivakumar T, Fukushi S, Tattiyapong M, Tuvshintulga B, Kothalawala $\mathrm{H}$, et al. Genetic diversity in Trypanosoma theileri from Sri Lankan cattle and water buffaloes. Vet Parasitol. 2015;207:335-41.

16. Ferrer L. Clinical aspects of canine leishmaniasis. In: R Killick-Kendrick, editor. Canine leishmaniasis: an updat. Proceedings of a Canine Leishmaniasis Forum. Barcelona: Hoeschst Roussel Vet; 1999. p. 6-10.

17. Assis TSM, Braga ASC, Pedras MJ, Barral AMP, Siqueira IC, Costa CHN, et al. Validação do teste imunocromatográfico rápido IT-LEISH ${ }^{\circledR}$ para o diagnóstico da leishmaniose visceral humana. Epidemiol Serv Saúde Brasília. 2008;17:107-16.

18. Laurenti MD. Correlação entre o diagnóstico parasitológico e sorológico na leishmaniose visceral americana canina. Bol Epidemiol Paul. 2009;6:13-23.

19. Burns JM, Shreffler WG, Benson DR, Ghalib HW, Badaro R, Reed SG. Molecular characterization of a kinesin-related antigen of Leishmania chagasi that detects specific antibody in African and American visceral leishmaniasis. Proc Natl Acad Sci. 1993:90:775-9.

20. Mancianti F, Pedonese F, Poli A. Evaluation of dot enzyme-linked immunosorbent assay (dot-ELISA) for the serodiagnosis of canine leishmaniosis as compared with indirect immunofluorescence assay. Vet Parasitol. 1996:65:1-9.

21. Ferroglio E, Centaro E, Mignone W, Trisciuoglio A. Evaluation of an ELISA rapid device for the serological diagnosis of Leishmania infantum infection in dog as compared with immunofluorescence assay and Western blot. Vet Parasitol. 2006:144:162-6.

22. Hirschmann LC, Brod CS, Radin J, Simon CF, Recuero AL. Leishmaniose visceral canina: comparação de métodos sorológicos em cães de area indene do Rio Grande do Sul no Brasil. Rev Patol Trop. 2015;44:33-44. 
23. Yanh BB, Chen DL, Chen JP, Liao L, Hu XS, Xu JN. Analysis of kinetoplast cytochrome $\mathrm{b}$ gene of 16 Leishmania isolates from different foci of China: different species of Leishmania in China and their phylogenetic inference. Parasit Vectors. 2013;6:32.

24. Kuru T, Jirata D, Genetu A, Barr S, Mengistu Y, Aseffa A, et al. Leishmania aethiopica: identification and characterization of cathepsin L-like cysteine protease genes. Exp Parasitol. 2007;115:283-90.

25. Thompson JD, Gibson TJ, Plewniak F, Jeanmougin F, Higgins DG. The clustalX windons interface: flexible strategies for multiple sequence alignment aided by quality analysis tools. Nucleic Acids Res. 1997;25:4876-82.

26. Nicholas KB, Nicholas HB, Deerfield DW, Nicholas HBJ, DWI DWID, Nicholas $\mathrm{KB}$, et al. GeneDoc: analysis and visualization of genetic variation. Embnewnews. 1997:4:24

27. Swofford DL. PAUP: phylogenetic analysis using parsimony. Version $4 \mathrm{~b} 6$. Suderland: Sinauer Associates; 1998.

28. Huelsenbeck JP, Ronquist F. MRBAYES: Bayesian inference of phylogenetic trees. Bioinformatics. 2001;17:754-5.

29. El Tai NO, Osman OF, El Fari M, Presber W, Schönian G. Genetic heterogeneity of ribosomal internal transcribed spacer in clinical samples of Leishmania donovani spotted on filter paper as revealed by single-strand conformation polymorphisms and sequencing. Trans R Soc Trop Med Hyg. 2000;94:575-9.

30. Marcili A, Sperança MA, Costa AP, Madeira MF, Soares HS, Sanches CO, et al. Phylogenetic relationships of Leishmania species based on trypanosomatid barcode (SSU rDNA) and gGAPDH genes: taxonomic revision of Leishmania (L.) infantum chagasi in South America. Infect Genet Evol. 2014;25:44-51.

31. Akhoundi M, Kuhls K, Cannet A, Votýpka J, Marty P, Delaunay P, et al. A historical overview of the classification, evolution, and dispersion of Leishmania parasites and sandflies. PLoS Negl Trop Dis. 2016;10:3.

32. Maurício IL, Stothard JR, Miles MA. The strange case of Leishmania chagasi. Parasitol Today. 2000;16:188-9.

33. Lainson R, Shaw JJ. Evolution, classification and geographic distribution. In: Peters W, Killick-Kendrick R, editors. The Leishmaniases in biology and medicine. London: Academic Press; 1978. p. 1-120

34. Travi BL, Osorio Y, Becerra MT, Adler GH. Dynamics of Leishmania chagasi infection in small mammals of the undisturbed and degraded tropical dry forests of northern Colombia. Trans R Soc Trop Med Hyg. 1998;92:275-8.

35. Dávila AM, Momen H. Internal-transcribed-spacer (ITS) sequences used to explore phylogenetic relationships within Leishmania. Ann Trop Med Parasitol. 2000;94:651-4.

36. Luyo-Acero GE, Uezato H, Oshiro M, Takei K, Kariya K, Katakura K, et al. Sequence variation of the cytochrome $b$ gene of various human infecting members of the genus Leishmania and their phylogeny. Parasitology. 2004;128:483-91.

37. Fornazieri MA, Yamaguti HY, Moreira JH, Takemoto LE, Navarro PL, Hesbike RE. The Most common Otorhinolaryngologic manifestations of granulomatous diseases. Int Arch Otorhinolaryngol. 2008;12:362-5.

38. Souza IS, Naiff RD, Guimarães TC, Naiff MF, Cupolilo E, Rodrigues WA, et al. American cutaneous leishmaniasis due to Leishmania (Viannia) guyanensis as an initial clinical presentation of human immunodeficiency virus infection. J Eur Acad Dermatol Venereol. 1998;10:214-7.

39. Seidelin H. Leishmaniasis and Babesiasis in Yucatan. Ann Trop Med Parasitol. 1912;6:295-300.

40. Silveira FT, Lainson R, Shaw JJ, Souza AA, Ishikawa EA, Braga RR. Cutaneous leishmaniasis due to Leishmania (Leishmania) amazonensis in Amazonian Brazil, and the significance of a negative Montenegro skin-test in human infections. Trans R Soc Trop Med Hyg. 1991;85:735-8.

41. Martinez E, Le Pont F, Torrez M, Telleria J, Vargas F, Muñoz M, et al. A new focus of cutaneous leishmaniasis due to Leishmania amazonensis in a sub Andean region of Bolivia. Acta Trop. 1998;71:97-106.

42. Narvaez FJA, Medina-Peralta S, Vargas-Gonzalez A, Canto-Lara SB, EstradaParra S. The histopathology of cutaneous leishmaniasis due to Leishmania (Leishmania) Mexicana in the Yucatan peninsula, Mexico. Rev Inst Med Trop Sao Paulo. 2005:47:191-4.

43. Lindoso JAL, Cunha MA, Queiroz IT, Moreira CHV. Leishmaniasis-HIV coinfection: current challenges. HIV AIDS (Auckl). 2016;8:147-56.

44. Colmenares M, Constant SL, Kima PE, McMahon-Pratt D. Leishmania pifano pathogenesis: selective lack of a local cutaneous response in the absence of circulating antibody. Infect Immun. 2002;70:6597-605.

45. Montes OH, Guzmán SG, Gómez FM, Barker DC, Monroy-Ostria A. Analysis of Kinetoplast DNA from Mexican Isolates of Leishmania (L.) mexicana. Interdiscip Perspect Infect Dis. 2012. https://doi.org/10.1155/2012/279081.
46. Mendonza-Palomares C, Biteau N, Giroud C, Coustou V, Coetzer T,

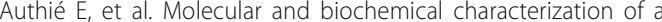
Cathepsin B-like protease family unique to Trypanosoma congolense. Eukaryot Cell. 2008;7:684-97.

47. Rodrigues AC, Garcia HA, Ortiz PA, Cortez AP, Martinkovic F, Paiva F, et al. Cysteine proteases of Trypanosoma (Megatrypanum) theileri: cathepsin L-like gene sequences as targets for phylogenetic analysis, genotyping diagnosis. Parasitol Int. 2010;58:318-25.

48. Lima L, Ortiz PA, Silva FM, Alves JM, Serrano MG, Cortez AP, et al. Repertoire, genealogy and genomic organization of cruzipain and homologous genes in Trypanosoma cruzi, T. cruzi-like and other trypanosome species. PLoS One. 2012;7:6.

49. Ortiz PA, Maia da Silva F, Cortez AP, Lima L, Campaner M, Pral EM, et al. Genes of cathepsin L-like proteases in Trypanosoma rangeli isolates: markers for diagnosis, genotyping and phylogenetic relationships. Acta Trop. 2009;112:249-59.

50. Denise H, Poot J, Jiménez $M$, Ambit A, Herrmann DC, Vermeulen AN, Coombs GH, et al. Studies on the CPA cysteine peptidase in the Leishmania infantum genome strain JPCM5. BMC Mol Biol. 2006;7:42.

51. Silva-Almeida M, Pereira BAS, Ribeiro-Guimarães $M L$, Alves $C R$. Proteinases as virulence factors in Leishmania spp. infection in mammals. Parasit Vectors. 2012;5:160.

52. Zampieri RA, Laranjeira-Silva MF, Muxel SM, Lima ACS, Shaw JJ, FloeterWinter LM. High resolution melting analysis targeting hsp70 as a fast and efficient method for the discrimination of Leishmania species. PLoS Negl Trop Dis. 2016;10:2.

53. Silva RP, Silva LAMT, Silva MAL, Alburquerque SCG, Goes TCG, Morais RCS, Melo $\mathrm{FL}$, Cavalcante MP. Evaluation of urine for Leishmania infantum DNA detection by real-time quantitative PCR. J Microbiol Methods. 2016;131:34-41.

54. Costa AP, Ferreira JIGS, Fournier GFSR, Lopes MG, Ramirez D, Acosta ICL, et al. Survey of Leishmania Infantum Chagasi in wild and domestic animals in urban area and Atlantic rainforest fragment in northeast, Brazil. J Biodivers Biopros Dev. 2014;1:2

55. Fraga DB, Pacheco LV, Borja LS, Tuy PG, Bastos LA, Solcà MS, Amorim LD, et al. The rapid test based on Leishmania infantum chimeric rK28 protein improves the diagnosis of canine visceral Leishmaniasis by reducing the detection of false-positive dogs. PLoS Negl Trop Dis. 2016;10:1.

56. Foulet F, Botterel F, Buffet P, Morizot G, Rivollet D, Deniau M, et al. Detection and identification of Leishmania species from clinical specimens by using a real-time PCR assay and sequencing of the cytochrome $b$ gene. J Clin Microbiol. 2007:45:2110-5.

57. Ceccarelli M, Galluzzi L, Migliazzo A, Magnani M. Detection and characterization of Leishmania (Leishmania) and Leishmania (Viannia) by SYBR green-based real-time PCR and high resolution melt analysis targeting kinetoplast minicircle DNA. PLoS One. 2014;9:2.

58. Ceccarelli M, Galluzzi L, Diotallevi A, Andreoni F, Fowler H, Petersen C, et al. The use of kDNA minicircle subclass relative abundance to differentiate between Leishmania (L.) infantum and Leishmania (L.) amazonensis. Parasit Vectors. 2017;10:1.

59. Dantas-Torres F, Sales KGS, Silva LG, Otranto D, Figueredo LA. LeishmaniaFAST15: a rapid, sensitive and low-cost real-time PCR assay for the detection of Leishmania infantum and Leishmania braziliensis kinetoplast DNA in canine blood samples. Mol Cell Probes. 2017;31:65-9.

60. Marfurt J, Niederwieser I, Makia ND, Beck HP, Felger I. Diagnostic genotyping of old and New World Leishmania species by PCR-RFLP. Diagn Microbiol Infect Dis. 2003;46:115-24.

61. Garcia FB, Santos SSR, Chociay MF, Medeiros ACR, Roselino AMF. Métodos subsidiários para o diagnóstico da Leishmaniose tegumentar americana (LTA): comparação dos resultados do seqüenciamento de DNA e da PCRRFLP para determinação da espécie de Leishmania em amostras cutâneomucosas. An Bras. 2005;80:339-44.

62. Mohammadi MA, Bamorovat M, Harandi MF, Karimi T, Sharifi I, Aflatoonian MR. Comparison of three PCR-based methods for simplicity and cost effectiveness identification of cutaneous Leishmaniasis due to Leishmania tropica. Iran J Parasitol. 2017;12:215-23.

\section{Publisher's Note}

Springer Nature remains neutral with regard to jurisdictional claims in published maps and institutional affiliations. 